\title{
5
}

UDC 631.46:665.61

\section{ACTUAL AND POTENTIAL ACTIVITY OF OIL-POLLUTED SOD-PODZOLIC SOIL BY ACTION OF PHYTOMELIORANT CAREX HIRTA L.}

\author{
L. V. Bunio, O. M. Tsvilynjuk \\ Ivan Franko National University of Lviv, 4, Hrushevskyi St., Lviv 79005, Ukraine \\ e-mail: bioza@ukr.net
}

In the field and laboratory experience oil pollution influence (5\%) on biological activity of sod-podzolic soil of Borislav with phytorecultavion activity of plants $C$. hirta was estimated. The carried out examinations have demonstrated low cellulose activity as in the background and model soil. In the oil-polluted soil, we determined higher resistance of urease compared to cellulase. Cellulase activity decreased, and urease activity increased at the oil pollution. Potential biological activity was higher in comparison with actual both at background and in oil-polluted soil. Oil contamination incremented anaerobic process of cellulose decomposing. Destruction of cellulose of filter disks from a soil surface was slower, than filter disks from beneath soil. The carried out examinations have demonstrated, that growth of $C$. hirta influenced variation of biological activity of oil-polluted soil. Growth of plants $C$. hirta enriched biological properties of the oilpolluted soil. In rhizosphere region of plants actual and potential activity was higher compared to a space between rows. Cellulase and urease activity of the background and oil-polluted soil in rhizosphere region of plants $C$. hirta was incremented compared to a row-spacing.

Keywords: sod-podzolic soil, actual and potential activity, oil contamination, rhizosphere, row-spacing, Carex hirta L.

\section{INTRODUCTION}

At last time, intensive degradation processes in soils is observed [6]. Anthropogenic degradation of soils often causes by oil and oil products that belong to priority pollutants of biosphere [2]. Oil pollution by soil damaged it stabile functioning: changed physical and chemical peculiarities, character of biochemical processes and activity of microbiota $[19 ; 23 ; 28]$. The most sensitive indicators of soil state are biological processes [22; 27], because of their first respond to oil pollution [3].

Biological activity is an important indicator of functional and toxicological soil state, production potential [16] and determines the level of potential and effective soil fertility [17; 45]. Changing of indicators complex of biological activity of soils, polluted by oil products, and their self-regeneration capacity can serve as early diagnostic features that allow to notice negative changes in the initial stages $[14 ; 20 ; 26 ; 34 ; 36]$. 
Biological soil activity is divided into actual and potential. Actual biological activity characterizes the real activity of soils in natural (field) conditions. Potential biological activity is soil activity, measured in artificial conditions, optimal for occurence of a particular biological process [37].

Among the biological characteristics can distinguished the most sensitive and characteristics: cellulase and urease activities of soil [12; 25], which can be determined by the decomposition rate in the soil of linen material and urea respectively [37]. Intensity of cellulose decomposition reflects tension of environmental situation and is complex indicator [42]. However, this indicator is advisable to use if there is an opportunity to put into the soil linen material on 30 days of exposure [3]. Determination of urease activity allows quickly determine the soils biochemical potential to assess their self-purification capacity [9].

Boryslav is a unique city in the world where up to now oil production is conducted. This led to the fact that the city soil is heavily polluted by oil and oil products. Since the remediation of soil from oil should be carried out in the city, the method must be safe for public health. One of these methods is the phytomelioration.

Plants resistant to oil pollution of Boryslav turf-podzolic soil are Carex hirta L. [39]. This plant is recommended for cleaning of oil-polluted soils [15]. In C. hirta was find mycorrhiza [40]. It may be one of the mechanisms of it resistance to oil pollution of soil. Plant roots with mycorrhiza characterized by high biological activity [13; 24].

Investigations on change in soil activity in the rhizosphere of resistant to oil pollution plants are very few. Therefore, soil activity was measured in soil artificial polluted by oil $(5 \%)$ in field and laboratory conditions in zones: the rhizosphere and space between rows.

\section{MATERIALS AND METHODS}

For the estimation of biological activity of soil, we had chosen two indicators: cellulase and urease activities. Has been field research methods which was complemented by laboratory methods. An experiment on the investigations of oil influence on biological activity of soil was begun in 2009-2013 in north-western part of Boryslav on the open country. Soil of this territory is sod-podzolic, loamy, covered by motley grass.

On $4 \mathrm{~m}^{2}$ areas were landed for 96 plants of $C$. hirta. An area of soil without adding of oil (background soil) served as a control. Area of soil artificially polluted by oil ( $\rho=$ $0.87 \mathrm{~g} / \mathrm{sm}^{3} ; 50 \mathrm{~g}$ of oil on $1 \mathrm{~kg}$ of soil) served as a model soil.

For creation of area was dug up a trench in $0.25 \mathrm{~m}$ depth and $1 \times 4 \mathrm{~m}$ size. The bottom of trench was covered by polyethylene tape with perforations. In every trench were brought in for $1000 \mathrm{~kg}$ soil at $15 \%$ of its humidity. In model soil were added $50 \mathrm{~kg}$ of oil and mixed. General area of experimental area was $40 \mathrm{~m}^{2}$, area of trench was $4 \mathrm{~m}^{2}$. Placing of trenches was successive. Experiment was repeated triple.

In 20 days after adding of oil (necessary term for evaporation of volatile toxic oil products) [27] the vegetative individuals of $C$. hirta were planted in soil. Plants were identical on age and sizes. Humidity of soil was supported within the limits of $60 \%$ from a complete moisture-capacity.

The selection of soil standards was carried out on 30 day of plants $C$. hirta growth, what corresponds to 50 day of oil destruction.

ISSN 1996-4536 • Біологічні Студії / Studia Biologica • 2014 • Том 8/№3-4 • C. 117-126 
Cellulase activity was determined in the field and laboratory conditions.

In the field conditions cellulase activity was determined on K. N. Mishustin's and I.V. Vostrov's applique method [33]. Linen material was mortgaged simultaneously with landing of plants on a depth 5-10 cm in the root area of plants and space between rows. The places with linen material were marked by lighthouses. Linen was exposed in soil during 30 days. Speed of linen material decomposition was determined on loss of it mass in dry state. Results were expressed in percent's from initial mass. Experiment was repeated 6-multiple.

In laboratory conditions C.G. Kristensen's method was used [44]: on the indexes of decreasing mass of cellulase substrate - filtration disks. On the bottom of sterile Petri dish were put sterile filtration disks. From above on them was laid out soil, water-wet to the sour cream similar state, and on it again were put sterile filtration disks. Account was conducted after 30 days. Experiment was repeated 3-times.

For determination of urease activity an express-method, offered by T.V. Aristovskaya and N.V. Chugunova, was used (on speed of urea decomposition at Petri dishes) [29]. Experiment was repeated 5-multiple.

Statistical processing of experimental data was conducted with the use of application in Microsoft Excel 2003 and Statistica 9.0 package.

\section{RESULTS AND DISCUSSION}

Cellulase activity of soil is an integral index wrap-round different soil processes. Determination of intensity of plant remains decomposition by method of linen materials decomposition objectively reflects activity of soil microbiota in the wild conditions.

In our field researches indexes of cellulase activity as in background so in model soils are small (table), that is characteristically for polluted sod-podzolic soils [5; 35] and coincides with literary data [30]. After 30 days cellulase activity of sod-podzolic oil-polluted soil in rhizosphere area was about $8 \%$ (Table) that was on $35 \%$ less than in rhizosphere area of background soil. In space between rows activity of model soil was only about $4.6 \%$ while in a control variant this index was on $51 \%$ higher (Table). The decreasing of linen material decomposition intensity on $35-51 \%$ is evidence of oil-pollution toxic effect in soil.

Less cellulase activity in space between rows in compared to rhizosphere area is related with creation of anaerobiosis in space between rows in great degree when in rhizosphere. Growth of roots friables in the soil and it in same time creates limiting conditions for development of anaerobic microorganisms at surplus of substrate [7].

In laboratory conditions destruction of filtration disks cellulose from the soil surface of control variant at 30 days arrived to $26.7 \%$ in rhizosphere and $20.9 \%$ in soil from space between rows (Fig. 1). At the same time cellulase activity of oil-polluted soil was $10.6 \%$ and $6.1 \%$ respectively, that almost on $60 \%$ and $70 \%$ less than in the control (Table).

On 30 days destruction of filtration disks cellulose from beneath soil was higher compared to destruction of filtration disks cellulose from surface of soil both in rhizosphere and in space between rows. However, in oil-polluted soil it was below on $39 \%$ in rhizosphere and on $85 \%$ in space between rows as was compared to the control (Table). Obviously, destruction of cellulose is carried out in a greater degree by anaerobic 
microorganisms decomposing cellulase. Soils of technogenic territories with low aeration [7] are characterized by high quantity of anaerobic microorganisms. Oil, impregnating with soil particles, creates favourable conditions for their development [18]. The main reason of low cellulose decomposition ability of oil-polluted soil is repression of cellulose degrading microorganisms' activity [31].

\section{Cellulose decomposition ability of oil-polluted soil at rhizosphere zone of C. hirta L. plants}

Здатність нафтозабрудненого ґрунту розщеплювати целюлозу в ризосферній зоні рослин C. hirta L.

\begin{tabular}{|c|c|c|c|c|}
\hline \multirow{2}{*}{ Variant } & \multirow{2}{*}{$\begin{array}{l}\text { Selection of soil } \\
\text { standards }\end{array}$} & \multirow{2}{*}{$\begin{array}{l}\text { Cellulase activity, } \\
\% \text { linen material } \\
\text { decomposition / } \\
\text { month }\end{array}$} & \multicolumn{2}{|c|}{$\begin{array}{c}\text { Cellulase activity, } \\
\% \text { filtration disks } \\
\text { decomposition / month }\end{array}$} \\
\hline & & & $\begin{array}{l}\text { Disk from surface } \\
\text { of soil }\end{array}$ & $\begin{array}{c}\text { Disk from beneath } \\
\text { soil }\end{array}$ \\
\hline \multirow{2}{*}{ 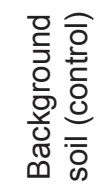 } & Rhizosphere & $12.9 \pm 2.3$ & $26.7 \pm 5.4$ & $43.1 \pm 4.7$ \\
\hline & Between rows & $9.3 \pm 2.4$ & $20.9 \pm 4.8$ & $38.8 \pm 6.2$ \\
\hline \multirow{2}{*}{ 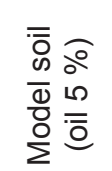 } & Rhizosphere & $8.4 \pm 2.7$ & $10.6 \pm 3.9$ & $26.5 \pm 3.5$ \\
\hline & Between rows & $4.6 \pm 1.2$ & $6.1 \pm 2.1$ & $5.7 \pm 1.8$ \\
\hline
\end{tabular}

Much higher indices of cellulose decomposition ability were in laboratory conditions when to compare with field conditions, obviously, related with this fact, that in laboratory experiment are created conditions for flowing of soil processes near to optimal and a difference in degree of worsening of soil properties between the control and polluted soil becomes more expressed. Thus, in the field conditions maintenance of oil in soil is not unique ecological factor which is not in an optimum, accordingly and difference between the values of biological indexes of polluted and unpolluted soils is shaded.

Urease possesses strict specificity of action: it decomposes only urea and does not influence on its derivative compounds [10]. Urease activity in investigational soils was different (Fig. 2).

The level of urease activity for the actions of oil was increased on $30 \%$ in a rhizosphere and on $40 \%$ in space between rows compared to the control. Increasing of urease activity in oil-polluted soils was looked after [18]. Stimulant actions on urease activity have $n$-paraffin hydrocarbons and cyclic hydrocarbons, that including to oil composition [18]. Oil and oil products stimulate urease activity, because activity of urease in direct ratio depends on maintenance of organic carbon in soil [8; 43].

High level of urease activity and its rapid growth in polluted standards suggests about high stability of this enzyme to inhibiting factors. It is necessary to suppose that this enzyme plays an important role in self-cleaning of such soils [11].

ISSN 1996-4536 • Біологічні Студії / Studia Biologica • 2014 • Том 8/№3-4 • С. 117-126 

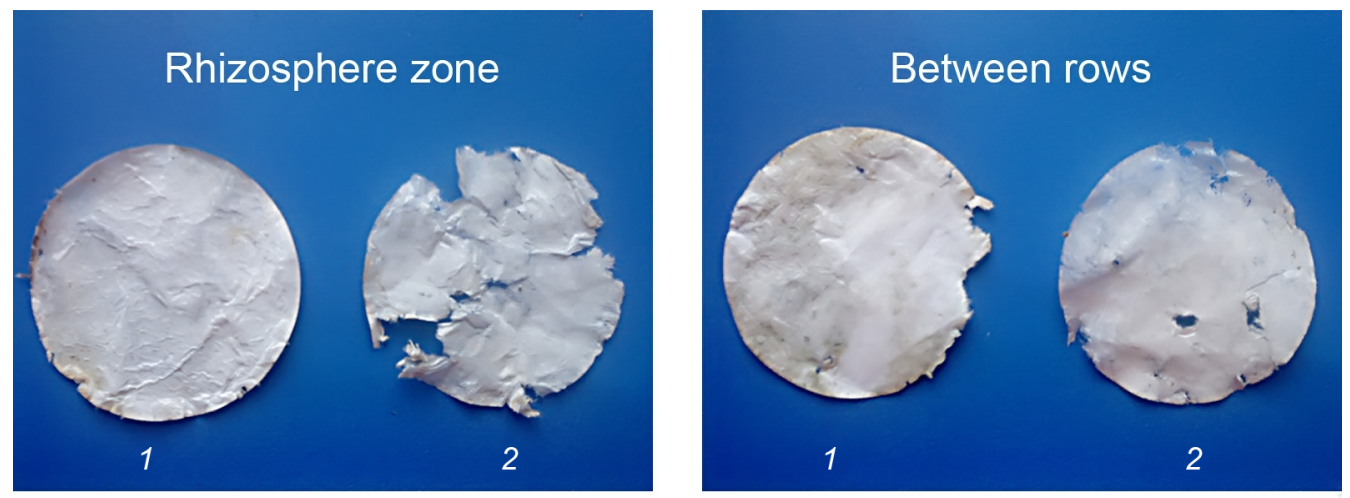

\section{BACKGROUND SOIL}
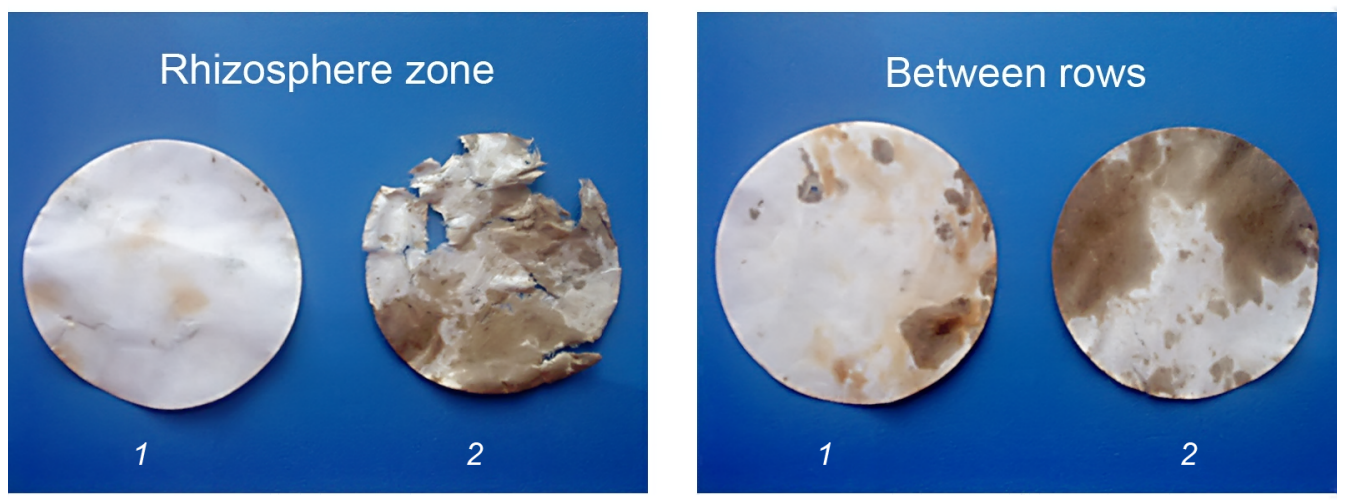

\section{MODEL SOIL}

Fig. 1. Cellulose decomposition ability of soil at 30 day (laboratory experiment): 1 is from surface of soil; 2 is from beneath soil

Рис. 1. Здатність ґрунту розщеплювати целюлозу на 30 день (лабораторний експеримент): 1 - 3 поверхні ґрунту; 2 - із-під ґрунту

In background soil in space between rows, urease activity was $20 \%$ lower on compared to the control, and the process of urea decomposition developed slowly. It is related with small quantity of organic compounds [10]. In the rhizosphere zone of background soil, urease activity was $70 \%$ higer than in the control (Fig. 2). The high rate of urea decomposition in the investigated soils characterizes potential self-cleaning ability of soil cover [11; 43]. It is one of important ecological functions of soil which is able to provide a defense of soil and contiguous environments, both from chemical and bacterial contamination [32].

\section{CONCLUSIONS}

Oil pollution of soil causes a change of its biological activity. In conditions of oil contamination cellulase activity decreases, but urease activity increases. It suggests self-cleaning activity of soil. 


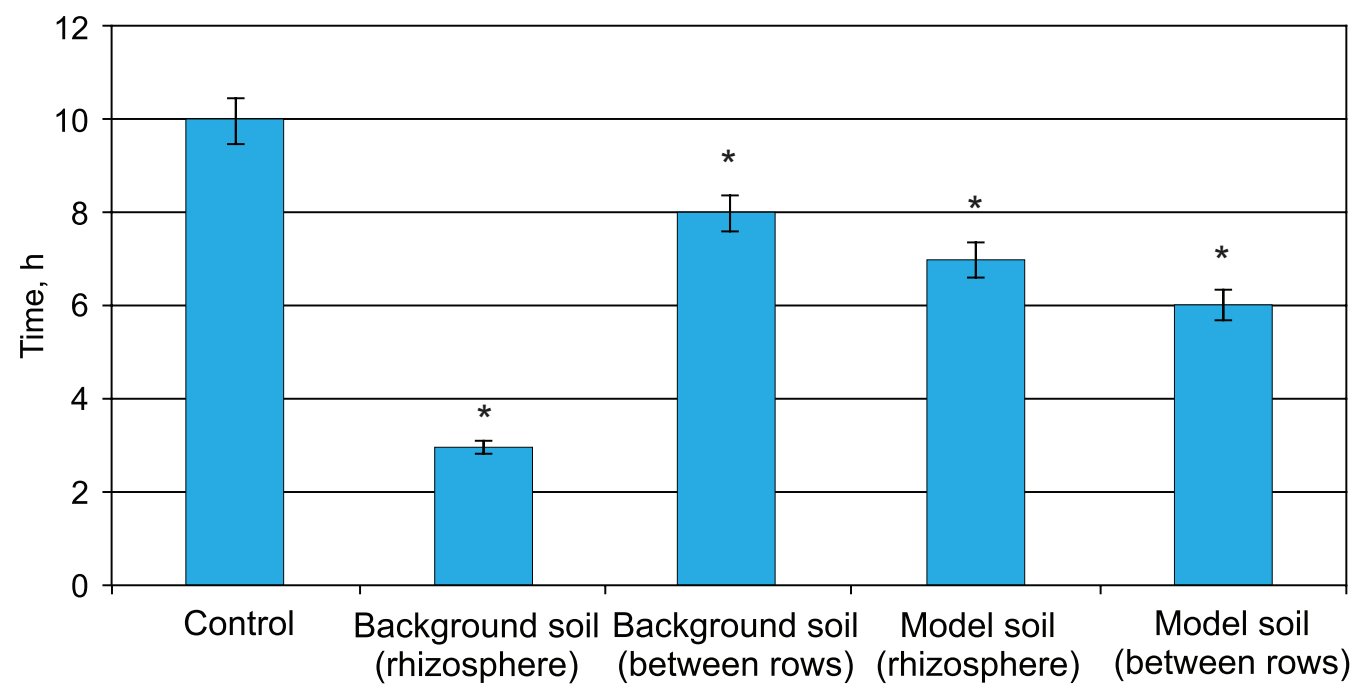

Fig. 2. Urease activity of sod-podzolic soil ( $P \leq 0.05 ; n=5)$

Рис. 2. Уреазна активність дерново-підзолистого ґрунту ('P $\leq 0,05 ; n=5)$

Oil pollution inhibited intensity of cellulose decomposition in soil. Combination of moisture limit and acid environment made oppressive influence on cellulase activity.

In space between rows cellulase activity (actual) is less compared to rhizosphere, but potential is vice versa higher.

In conditions of oil pollution, the anaerobic process of cellulose decomposition in soil increased.

High level of urease activity in polluted standards suggests high stability of this enzyme to inhibiting factors. It is supposed that this enzyme plays an important role in self-cleaning activity of such soils.

Potential biological activity was higher than actual both in background and oil polluted soil conditions.

1. Aristovskaya T.V., Chugunova N.V. Rapid method for determining the biological activity of the soil. Soil Science, 1989; 11: 142-147. (In Russian).

2. Arzhannikov V. P., Gromova O. V. Agromelioration - an effective method of restoring the biocapacity of contaminated lands in the North. In: V Intern. conf. "The development of the North and the updating problems remediation (5-8 June 2001). Syktyvkar, 2001: 8-9. (In Russian).

3. Aznauryan D.K. Changing ecological and biological properties of oil polluted soils of the south Russia: PhD. Rostov-on-Don, 2009. 151 p. (In Russian).

4. Condition soils Ukraine. Series: "Environmental Protection". In: Tarariko O. G. (Ed.). Kyiv: Aspect-Poligraf, 2005; 3 (15): 32 p. (In Ukrainian).

5. Demyanyuk O.S., Sherstoboyeva O.V. Potential cellulolytic activity of soils of different Ukraine agroecosystems. Agroecology Journal, 2005; 5: 56-59. (In Ukrainian).

6. Dobrovolskiy G.V. Place and role of soil science in studying and solving environmental problems today. Visnyk of Moscow University. Soil Science, 2006. 17(2): 3-7. (In Russian). 
7. Dolgova L.G. Activity of some oxidoreductases under pollution. Reports of $\mathbf{5}$ delegating the company Union Congress of Soil Science. Minsk, 1977; 2: 267-269. (In Russian).

8. Emtsev V.T. Microbiology. Moskow: Drofa, 2005. 445 p. (In Russian).

9. Fedoretc N.G., Medvedeva M. V. Methodology study of soils in urban areas. Petrozavodsk: Karelian Research Centre of RAS, 2009. 84 p. (In Russian).

10. Feoktistova I.D. Evaluation of the ecological state of soils in urban areas contaminated with oil and heavy metals (on the example of Vladimir): Synopsis PhD. Vladimir, 2012. 22 p. (In Russian).

11. Feoktistova I.D., Sahno O.N., Zhuravleva A.G. Ecological status of soils evaluation in urban areas polluted with oil. Bulletin of the Samara Scientific Center of the Russian Academy of Sciences, 2011; 13(1 (5): 1233-1235. (In Russian).

12. Gayvoronskiy V.G. Kolesnikov S.I. Pollution modeling of chernozem and brown forest soil with fuel oil to determine its environmentally safe concentration. Math. Universities. NorthCaucasus. Region. Natures. Science, 2008; 4: 86-88. (In Russian).

13. Hazeev F.H. Soil enzymology methods. Moscow: Nauka, 2005. 252 p. (In Russian).

14. Inisheva L.I., Ivleva S.N., Shcherbakova T.A. Guidelines for the determination of the enzymatic activity of soils and peats. Tomsk: Publishing of Tomsk University, 2003. 122 p. (In Russian).

15. Jura N.M., Terek O.I. Tsvilynyuk O.M. Method remediation of oil polluted soils. Patent for utility model 16345 Ukraine, IPC (2006) 79 A01V / A01V 00 79/02 (2006.01) A01S 21/00, 2006; 8: 7 p. (In Ukrainian).

16. Kabirov R.R., Safiullina L.M., Kireeva N.A. et al. Evaluating the biological activity of oilpolluted soils using a complex index. Eurasian Soil Science, 2012; 45(2): 157-161. (In Russian).

17. Karyagina L.A. Microbiological basis for improving soil fertility. Minsk: Science and Technology, 1983. 181 p. (In Russian).

18. Kireeva N.A., Vodop'yanov V. V., Miftahova A.M. Biological Activity of oil-contaminated soil. Ufa: Guillem, 2001. 376 p. (In Russian).

19. Kiss S. Advences in soil enzymology (Part I-II). Studia Univesitates Bades-Bolyai Biologia, 2001; 1: 3-48.

20. Kiss S., Dragan-Bularda M., Pasca D. Enzymolodgy of technogenic soils. Cluj, 1993. 96 p.

21. Kolesnikov S.I., Kazeev K.Sh., Tatosyan M.L. et al. The effect of pollution with oil and oil products on the biological status of ordinary chernozems. Soil Science, 2006; 39 (5): 552-556. (In Russian).

22. Kolesnikov S. I., Tlehas Z. R., Kazeev K. Sh. et al. Effect of Contamination with Heavy Metals and Oil on the Biological Properties of Leached Vertic Chernozem. Agrokhimija, 2010; 7: 62-67. (In Russian).

23. Margesin R., Zimmerbauer A., Schinner F. Monitoring of bioremedia-tion by soil biological activities. Chemosphere, 2000; 40: 339-346.

24. Miftahova A.M. Self-cleaning and soil fertility restoration of natural and anthropogenic ecosystems in terms of oil pollution. In: PhD. Ufa: Institute of Ecology of the Volga Basin Russia Academy of Sciences, 2006. 361p. (In Russian).

25. Naumovska O.I., Yevpak I.V., Manishevska N.M. et al. Biological activity of typical chernozem soil in the application of technology growing crops. Visnyk Kharkov National Agrarian University. Soil Science, 2004; 6: 141-145. (In Ukrainian).

26. Passa D., Kiss $S$. Enzymatic potential of some highmoor peats froom Romania. Proceeding $10^{\text {th }}$ International Peat Congress. Bremen, Stuttgart, 1996; 2: 548-553.

27. Pikovskiy Y.I., Gennadiev A.N., Chernyanskiy S.S. et al. The problem of diagnostics and standardization of the levels of soil pollution by oil and oil products. Soil Science, 2003; 36(9): 1010-1017. (In Russian). 
28. Rakhimova E.R., Garusov A.V., Zaripova S.K. Biological activity of oil-contaminated soil upon its salinization. Soil Science, 2005; 4: 481-485. (In Russian).

29. Rudenko S.S., Kostishun S. S., Morozova T.V. General Ecology. (Part II). Natural Terrestrial Ecosystems. Chernivtsi: Books XXI, 2008. 308 p. (In Ukrainian).

30. Rylova N.G., Stepus N.F. The change of cellulose soil activity as a result of pollution with heavy metals. Vestnik of Udmurt. University, 2005; 10: 65-70. (In Russian).

31. Samosova S.M., Filchikova V.I., Kiprova R.R. et al. Activity microflora of chernozem in the oil pollution. Kazan: Dep. VINITI, 1983. 19 p. (In Russian).

32. Schemelinina T.N. Biological Activity north contaminated soils at different stages of their recovery and recultivation: Synopsis $\mathrm{PhD}$. Voronezh: Institute of Biology, Komi Scientific Center, 2008. 22 p. (In Russian).

33. Scherbakov V.J., Mishin S.N., Pochkolina S.V. Microbiological activity of soil and soil microbial symbiosis with soybeans under fertilizers and herbicides. Visnyk of Poltava State Agricultural Institute, 1999. 13-14. (In Ukrainian).

34. Sevost'yanov A.V. Mass valuation of urban lands in the works in urban cadastre. Training and methodological support vocational training land and real estate appraisers. Moscow: Moscow State University of Land Management, 2001; 9: 68 p. (In Russian).

35. Shusteruk T.Z. Environmental assessment of human impacts on soil biotic activity (for agroecosystems Ukraine example): PhD. Kyiv, 2007. 27 p. (In Ukrainian).

36. Tarasenko E.M. Biological activity and toxicity of soils at oil contamination and remediation: PhD. Ufa, 2006. 145 p. (In Russian).

37. Tatosyan M.L. Oil and oil products pollution effect on the biological activity of chernozem: PhD. Rostov-on-Don, 2003. 175 p. (In Russian).

38. Trishina G. G., Antonik I. P. Assessment of Ecological Security of Krivbas soil during operation of the oil pumping station "Shiroke" PAT "UkrTransNafta". Visnyk of the Kryvyi Rih National University, 2012; 32: 127-132 (In Ukrainian).

39. Tsaytler M.J. Changes in the structure Carex hirta cenopopulations in terms of oil pollution on Boryslav oil field ecotypes. Ecology and Noosferolohiya, 2000; 9(1-2): 127-132. (In Ukrainian).

40. Tsvilynyuk O.M, Bunio L.V., Karpyn O.L. et al. Mycorrhizae as part of the survival stategy of Carex hirta L. ona crude oil contaminated soil. Visnyk of Lviv University. Series Biology, 2012; 60: 320-326. (In Ukrainian).

41. Yakovlev A. S. Biological diagnosis and monitoring of soils. Soil Science, 2000; 1: 70-79. (In Russian).

42. Yakovlev A.S., Nikulina Y.G. Ecological rating of the allowable residual oil content in soils of different land uses. Soil Science, 2013; 46 (2): 212-216. (In Russian).

43. Zabelina O.N., Trifonova T.A. Application of indicators biological activity in the environmental condition of urban soils. Collected Materials of the IV Intern. sci. conf. "Ecology of the Regions". Vladimir: VOOO VOI, 2012: 46-49. (In Russian).

44. Zenova G.M., Stepanov A.L., Lihacheva A.A. et al. Workshop on soil biology. Moscow: Moscow State University, 2002. 120 p. (In Russian).

45. Zvyagintsev D.G., Babieva I.P., Zenova G.M. Soils Biology. Moscow: Moscow State University, 2005. 445 p. (In Russian).

ISSN 1996-4536 • Біологічні Студії / Studia Biologica • 2014 • Том 8/№3-4 • С. 117-126 


\title{
АКТУАЛЬНА I ПОТЕНЦІАЛЬНА АКТИВНІСТЬ НАФТОЗАБРУДНЕНОГО ДЕРНОВО-ПІДЗОЛИСТОГО ҐРУНТУ ЗА ДІЇ ФІТОМЕЛІОРАНТА САRЕХ HIRTA L.
}

\author{
Л. В. Буньо, О. М. Цвілинюк \\ Львівський національний університет імені Івана Франка \\ вул. Грушевського, 4, Львів 79005, Україна \\ e-mail: bioza@ukr.net
}

У польовому модельному та лабораторному дослідах виявлено вплив нафтового забруднення (5 \%) на біологічну активність дерново-підзолистого ґрунту м. Борислава із використанням рослин C. hirta для фріторекультивації. У результаті наших досліджень було встановлено зміну біологічної активності нафтозабрудненого ґрунту. Проведені дослідження довели, що целюлозолітична активність як фонового, так і нафртозабрудненого ґрунтів була низькою. У нафртозабрудненому ґрунті виявили більшу стійкість фрерменту уреази, порівняно з целюлазою. Целюлозолітична активність зменшувалась, а уреазна активність зростала у нафртозабрудненому ґрунті. Потенціальна біологічна активність була вищою, порівняно з актуальною, як у фоновому, так і у нафтозабрудненому ґрунтах. Нафтове забруднення ґрунту збільшувало анаеробний процес розкладу целюлози. Деструкція целюлози фрільтрувальних дисків з поверхні ґрунту відбувалася повільніше, ніж деструкція целюлози фрільтрувальних дисків з-під ґрунту. Під час дослідження з'ясовано, що ріст C. hirta впливав на зміну біологічної активності нафртозабрудненого ґрунту. Ріст рослин C. hirta покращував біологічні властивості нафртозабрудненого ґрунту. У ризосферній зоні рослин актуальна та потенціальна активність була вищою, порівняно з міжряддям. Целюлозолітична й уреазна активність фонового і нафтозабрудненого ґрунтів у ризосферній зоні рослин C. hirta зростала, порівняно з міжряддям.

Ключові слова: дерново-підзолистий ґрунт, актуальна і потенціальна активність, нафртове забруднення, ризосфера, міжряддя, Carex hirta L.

\section{АКТУАЛЬНАЯ И ПОТЕНЦИАЛЬНАЯ АКТИВНОСТЬ НЕФТЕЗАГРЯЗНЕННОЙ ДЕРНОВО-ПОДЗОЛИСТОЙ ПОЧВЫ ПРИ ДЕЙСТВИИ ФИТОМЕЛИОРАНТА CAREX HIRTA L.}

\author{
Л. В. Буньо, О. М. Цвилынюк \\ Львовский национальный университет имени Ивана Франко \\ ул. Грушевского, 4, Львов 79005, Украина \\ e-mail: bioza@ukr.net
}

В полевом модельном и лабораторном опытах выявлено влияние нефтяного загрязнения (5 \%) на биологическую активность дерново-подзолистой почвы г. Борислава с использованием растений C. hirta для фиторекультивации. В результате наших исследований было установлено изменение биологической активности почвы при нефтяном загрязнении. Проведенные исследования показали, что целлюлозолитическая активность как фоновой, так и нефртезагрязненной почв была низкой. В нефтезагрязненной почве обнаружили большую устойчивость фрермента 
уреазы, по сравнению с целлюлазой. Целлюлозолитическая активность уменьшалась, а уреазная активность возрастала при нефтяном загрязнении почвы. Потенциальная биологическая активность была выше, по сравнению с актуальной, как в фооновой, так и в нефтезагрязненной почвах. Нефтяное загрязнение почвы увеличивало анаэробный процесс разложения целлюлозы. Деструкция целлюлозы фрильтрирующих дисков с поверхности почвы происходила медленнее, чем деструкция целлюлозы фильтровальных дисков из глубины почвы. Проведенные исследования показали, что рост C. hirta влиял на изменение биологической активности нефтезагрязненной почвы. Рост растений C. hirta улучшал биологические свойства нефтезагрязненной почвы. В ризосферной зоне растений актуальная и потенциальная активность была выше, по сравнению с междурядьем. Целлюлозолитическея и уреазная активность фоновой и нефтезагрязненной почв в ризосферной зоне растений C. hirta увеличивалась, по сравнению с междурядьем.

Ключевые слова: дерново-подзолистая почва, актуальная и потенциальная активность, нефтяное загрязнение, ризосфера, междурядье, Carex hirta L.

Одержано: 14.10 .2014 